\title{
New worlds, imaginary spaces and contingent reality: Columbus and astrology
}

In this week when it seems the whole world is either mourning or celebrating the arrival of Columbus in the Bahamas some 500 years ago, 1 have taken some pains to devise a paper which attempts to negotiate the Atlantic squalls which the Columbus quincentenary has been so successful in generating. Last Wednesday, which was 12 October, Quincentenary Day, the Australian carried a story with the beadline, 'Ideology hijacks Columbus anniversary', lamenting the attacks on Columbus, the 'Renaissance man' and a 'weaver's son from Genoa' by the liberal establishment and aggrieved native Americans.' Even Felipe Fernández-Armesto, whose latest biography of Columbus ${ }^{2}$ paints a far from flattering portrait of the great discoverer as a 'representative figure of his day', ${ }^{3}$ feels the countermovement has gone too far. Fernandez-Armesto describes the claim that Latin America was created by a 'crime of genocide initiated by Columbus' to be 'a wicked lie'. ${ }^{4}$

Sydney's own Renaissance Man and explorer, Jonathon King, has weighed into the Columbus debate in the Australian press, based on his experience as a participant on the recent re-enactment of the Columbus crossing, ${ }^{5}$ not to mention the published conclusions of generations of Columbus scholars. For King, and the aforementioned scholars and sailors, the wind conditions confirmed that Columbus was a cheat and a liar. Not only did he deliberately deceive the sailors on his original voyage as to the number of leagues travelled, he also concealed the route taken, which was not due west due to the prevailing winds, but south into the latitudes of Portuguese monopoly where he could pick up north-east trade winds.

All the media coverage has as an implicit assumption the belief that there is a real Columbus and a real voyage across a distinct spatial route that awaits uncovering. And yet it is just this which is most open to doubt. All

1 The Australian, 12 October 1992: original story by Richard Caseby of the Sunday Times, additional reporting by Philip Wedme and others.

2 Felipe Fernández-Armesto, Columbus, Oxford, 1992.

3 Ibid., p. 21.

4 lbid.

5 The Australian Weekend Review, 10-11 October 1992. 
our information about the first Columbus crossing is riddled with difficulty, hidden behind layers of textual, navigational, instrumental, and historical problems. That Columbus may have lied deliberately about the route of the first voyage is really the least of the matters obscuring this peculiarly significant past. To the images of Columbus the cheat and liar, the perpetrator of genocide, and the hero of the New World, one might add the multiple other identities concocted for him by scholars, politicians, admirers, and detractors and, not least of all, himself. Among so many images of the discoverer available for construction and deconstruction, can we doubt that we are in the realm of 'contingent reality', which is in the title of my paper?

The purpose of my paper is not to attempt to add anything to the vast flood of Columbus scholarship, both extant and generated for this year of commemorations, but to explore some ideas about the nature of exploration and contingency, both spatial and temporal, in the first voyage of Columbus and in medieval astrology. For some of these ideas, I acknowledge a debt to Paul Carter's scminal study of Australian exploration. ${ }^{6}$

I thought it might be simplest to begin by demonstrating the various layers of obscurity which overlay the first Columbus voyage. I stress, of course, that all of this information is well known to scholars. 7

All Columbus scholars struggle with the limitations of the texts. David Henige's monograph on the sources for the first voyage is particularly sceptical. ${ }^{8}$ This, in brief, is the state of affairs.

Columbus's shipboard account of the voyage, both the secret 'daily' $\log$, in which he recorded his own grossly inflated estimate of the distances covered, and the readings be gave out for the supposed deception of the sailors, are no longer extant. Nor is the manuscript of the fine copy which

6 Paul Carter, The Road to Botany Bay. An Essay in Spatial History, London and Boston, MA, 1987.

7 I have relied in particular on Felipe Fernández-Armesto, Columbus, and Cecil Jane, ed., Select Documents illustrating the four voyages of Columbus, 2 vols., Hakluyt Society, 1930 and 1933.

8 David Henige, In Search of Columbus: The Sources for the First Voyage, Tucson, AZ, 1992. More optimistic is the journal's editor, John Cummins, The Voyage of Christopher Columbus: Columbus's Own Journal of Discovery, London, 1992. 
Columbus is likely to have made while still on board for presentation to Ferdinand and Isabella and possibly for publication. ${ }^{9}$ This may have gone under the title Libro de la primers navegacion (Book of the first navigation). This was not published, although there were probably a number of manuscript copies of this text, all interfered with:to a greater or lesser extent, and we do not have those either. What exists is the abridgment of the Book of the first navigation compiled between 1550 and 1563 by Bartolome de Las Casas for his own pious and polemical purposes. The abridgment was published by Las Casas under the tille El primer viaje (The first voyage) in his History of the Indies. ${ }^{10}$ It is an English translation of the Las Casas text which was read on ABC radio in 1992 to commemorate the event, and it is usually referred to as Columbus's 'jounnal' or 'diario'.

The process by which Columbus's contemporary experiences became encoded first as the ship's log, then as the narrative 'Journal', later as the Book of the first navigation, and finally, in the bands of Las Casas, as The first voyage, gives all historians pause to consider the chancy nature of manuscript survival and historical evidence. It is a remarkable feature of the Columbus logs that the pathway of transmission is relatively clear.

The textual problems of the accounts of the first Columbus voyage must be seen as primary to the contingencies of interpretation of much else that hovers in contention around Columbus, which is why I have addressed the matter briefly here. The scholar who wishes to discover the route taken by Columbus on that first planned crossing of the Atlantic must first navigate through the shoals of textual difficulty. But there are further snags ahead.

Let us look now at the journey itself. All books about Columbus carry maps. These maps invariably includes lines of passage marking the supposed passage of Columbus on his various joumeys. The map from the special Columbus edition of History Today ${ }^{11}$ is quite typical in showing a solid line (with arrows) marking the voyage, complete with neatly aligned changes of course and a definite landing point. It is hard to be specific but it

9 Columbus's son Ferdinand tells us that Columbus's hand was so fine that be could have made a living from this skill alone, so the journal submitted to the monarchs of Castille may not have been re-written.

10 A. Millares Carlo, ed., B. de Las Casas, Historia de las Indias, 3 vols., Mexico City-Buenos Aires, 1951.

11 History Today 42 (May 1992), 5. 
looks as though the illustrator has plumped for a landing on San Salvador, which is where tradition and the Columbus Monument, but not necessarily of course the ambiguous Book of the first navigation, says it should be. ${ }^{12}$ Among bogus maps of the first Columbus voyage, I was particularly taken with the one which illustrates an English translation of the admiral's Life by his son Ferdinand, written before Ferdinand's death in 1539. Not only does it show the route with a nice black line, it also gives position readings for every couple of days. ${ }^{13}$

Even the cautious Fernandez-Armesto, whose text methodically and amusingly documents the futility of attempting to determine exactly which route Columbus took on his first voyage, provides one map which does just this. ${ }^{14}$ The line is there even though it is attached to a disclaimer, 'true angle of approach and location of landfall cannot be reliably determined'. His map of the Bahamas is more scrupulous and may just be unique in that it provides no line of travel for this part of Columbus's joumey. ${ }^{15}$ But the line reappears in all its solidity in the map which accompanies FernandezArmesto's History Today article. ${ }^{16}$

The various difficulties which prevent us ever knowing exactly the route taken by Columbus on the first voyage can be resolved into four basic issues: textual, cosmological, navigational, and political. The first, which is the textual problem of how the original data of the first voyage was transmitted to the surviving account, has been considered above. The second issue concerns the cosmology.

Cosmological problems pose at least as great a difficulty to a complete understanding of the Columbus event. Columbus never conceded that his 'discoveries' were not located in eastern Asia, nor did he ever give up hope of finding the emissaries of the Great Khan, the island of Cipangu and the land of Cathay. The 'real' route of Columbus's voyage lies imposed upon

12 Watlings Island was renamed 'San Salvador' in 1926 to reinforce its claims to be the Columbus landing point.

13 The life of the Admiral Christopher Columbus by his son Ferdinand, trans. and annotated by Benjamin Keen, New Brunswick, NJ, 1959.

14 Fernández-Armesto, Columbus, map entitled 'Columbus's Routes across the Atlantic'.

15 Ibid., 'Columbus in the West Indies'. The disclaimer to the lineless part of the map reads: 'course unknown through Bahamas; three islands explored'.

16 History Today 42, 5. 
the cosmology of Columbus's pre-voyage reading in medieval geography, his wishful thinking of a small earth and his personal voyaging in the Atlantic. ${ }^{17}$

The chimerical path of the first Columbus voyage was not exploration so much as free fall into a conjectured cosmology. This cosmology was constructed from his reading of Pierre d'Ailly, particularly the Ymago mundi (The image of the world), Marco Polo, and Sir John Mandeville, and their classical and medieval sources: Ptolemy, Marinus of Tyre, Pliny, Strabo, and Seneca, ${ }^{18}$ as well as the maps depicting this conjectural universe.

The authorities and his own conviction created these land forms for him. They gave him the courage to undertake the longest voyage ever knowingly undertaken between landfalls on the open sea. We can not recapture the line of Columbus's first voyage, but we do know the cosmology through which he voyaged. This cosmology was, in our terms, an imaginary world, albeit mapped and verified by the best authorities, not the New World which Columbus always refused to acknowledge.

The third issue concerns Columbus's navigation, which has been so variously estimated in the past.

Columbus was not a scientific navigator. Perhaps this is more difficult for Australians to accept than others. Columbus was not like Cook, that most rational and expert of discoverers travelling with a method for calculating longitude and plenty of money, or like Bligh, whose bad language allowed him to demonstrate his mastery of navigation. ${ }^{19}$ Columbus is more like the other explorers of the imaginary world, Galahad, perhaps, seeking the Grail, Marco Polo providing fantastic falsehoods to corroborate a too incredible truth, Sir John Mandeville or Sinbad.

Columbus seems most like Marco Polo and least like James Cook, when we look at his navigational techniques. Longitude could not be determined with any accuracy by Columbus or anyone else in the fifteenth century. A rough guide to longitude can be devised by noting the distance travelled, but Columbus had fixated on the figure of $562 / 3$ Roman miles for each degree, which led him to exaggerate both his distance travelled and the

17 This landscape is evoked in Valeric I. J. Flint, The Imaginative Landscape of Christopher Columbus, Princeton, NJ, 1992.

18 For a brief review of this topic see, as well as Flint, The Imaginative Landscape; Helen Wallis, 'What Columbus Knew', in History Today 42, 17-23. 19 Greg Denning, Mr Bligh's Bad Language, Melbourne, 1992. 
degrees of longitude his expedition had traversed. When he had an eclipse to assist in completing this vital measurement, he fluffed the reading. Even if he had the skill, an imaginary world is not amenable to longitude.

Latitude can be calculated, as Pierre d'Ailly outlined in the book so thoroughly read by Columbus, by taking a reading of the angle of elevation of the sun or the Pole Star, 20 but Columbus was never able to do this. Rather be noted the length of the night hours, subtracting them to find daylength and checked this against the table supplied by Pierre d'Ailly in the Ymago mundi. ${ }^{21}$ Or, as he tells us in the log of the return voyage, he took a reading by eye of the elevation of the Pole Star and checked it against his recollection of the elevation at ports in Europe.

Columbus took navigational instruments with him, including a compass, sand-filled hour-glasses, and probably a quadrant and astrolabe. There may have been others, such as a traverse table. ${ }^{22}$ Due to the roll of the ship he was not able to use his astrolabe and quadrant with any accuracy and according to Las Casas the crew found his use of them a major irritation. Ferdinand says the crew plotted to 'heave him overboard and report in Spain that he had fallen in accidentally while observing the star. ${ }^{23}$

The fourth issue turns on the politics of the voyage.

As mentioned above, political factors might seem to be the least of our difficulties in finding the path of Columbus's first voyage. Claims to title in European law, however, depended on demonstration of prior discovery. The court version of the journal, copied and distributed in manuscript, was probably altered to secure Spanish claims to Columbus's discoveries.

Like all myths, the Columbus story demonstrates a need to focus on origins and first moments. The popular and scholarly drive to determine the precise path taken by Columbus across the Allantic also reveals a need to define Columbus in terms of his journeys. As an explorer, be must follow a discernible path. As a pioneer he must lay down a track for others to

20 A Source Book in Medieval Science, ed. Edward Grant; no. 81 is an abridged translation of The Image of the World by Pierre d'Ailly (1350-1420) with the marginal comments of Christopher Columbus.

21 See Fernández-Armesto, Columbus, pp. 76-77, for navigational instruments and the note that the mistakes made by Columbus in bis latitude correspond to misprints in the table.

22 This was suggested by Associate-Professor John Pryor at the conference.

23 The Life of the Admiral, p. 52. 
follow. It does not seem to matter that it is not possible to lay down paths on the sea. Indeed, as a skilled practical sailor on a dangerous voyage, it was essential that Columbus read the sea and follow the winds he had learned by experience to negotiate rather than that be attempt the impossible task of laying down or subsequently following such an invisible trail. Columbus aimed to go there and back again, like Orpheus to the underworld, and tell others how to follow him. Perbaps the best evidence for this is the inexplicable failure of Columbus to produce a map of his discoveries, although he was urged to do so directly by Isabella for pressing diplomatic reasons.

In the next part of my paper I would like to explore an idea about Columbus and his first voyage that arises from my research into the activities of late medieval astrologers. For it has struck me that his cosmology, his technology, his computational incompetence, and his trajectory across a contingent reality are all things he shares with astrologers. There is this important difference, of course, that in the case of Columbus the contingent reality was the space of the Atlantic and its imaginary geography. For astrologers, the contingent reality is future time and the imaginary cosmology of celestial influence.

Like any man of his time, Columbus believed in astrology. He also believed in prophecy, celestial voices, the coming of the Last World Emperor, and the liberation of Jerusalem, and these beliefs became more obsessional in the last part of his life. Unlike the evidence for the path of the first journey, there is excellent, original, contemporary and autograph evidence for these beliefs. He collected astrological jottings among other prophetic texts, and these are preserved, mirabile dictu, in his handwriting. ${ }^{24}$

The astrology Columbus believed in was always concerned with general celestial influence. He was an enthusiastic advocate of the doctrine of Great Conjunctions, which be read about in Pierre d'Ailly, no doubt largely because be believed that this event predicted his own discoveries and prophetic ambitions. ' But Columbus was a pious man and the orthodox theological view of astrology was hostile to the science of the stars,

24 See Fernández-Armesto, Columbus, p. 156, for discussion of the 'ill-kempt mass' of scriptural and prophetic texts including astrological notes, which Columbus compiled up till ca 1504. 
particularly to judicial astrology, that is, the making of particular judgments concerning individuals. Columbus's copy of d'Ailly's Ymago mundi, was bound together with the Cardinal's tract De legibus et sectis contra superstitiosos astronomos (On Laws and Sects against superstitious astrologers), one of a number d'Ailly wrote about astrology. Columbus made extensive annotations in his copy of this text, and mined it for prophetic texts to suit his later obsessions. D'Ailly was not so severe in his disapproval of astrology as Jean Gerson, some of whose tracts Columbus also possessed but did not annotate. 25 In the De legibus, dated Christmas Eve, 1410, d'Ailly rebuked superstitious astrologers, such as those who, like 'a certain English doctor', Roger Bacon perhaps, would put the Christian religion under the control of Mercury.

But for my purposes it does not really matter what Columbus himself thought about astrology. Someone so demonstrably incompetent at the calculation of longitude from eclipses would never have had the computational skill to cast horoscopes anyway, even if he had thought this practice was theologically defensible. For his part, however, the astrologer with his astrolabe and tables of planetary positions, his astrological authorities and negotiation of contingent futures, was like a desk-bound Columbus, right down to the sloppy arithmetic. Like Columbus, astrologers liked to pretend that they knew how to take accurate and direct observations of celestial phenomena with their astrolabes and quadrants. In reality, they used shortcuts, ready-made tables, and cribs. In this way they endlessly repeated centuries-old computational errors.

But for medieval astrologers, as for Columbus, this was not a serious problem. The calculation of the horoscope, like the first voyage, served more to confirm the existence of a known cosmology, an imaginary, not a new, world. Perhaps I might demonstrate this by reference to the English horoscopes I have collected from manuscripts and which relate to the period from the late thirteenth to the late fifteenth century. Medieval boroscopes are very rare. In order to find seventeen boroscopes, I searched the catalogue entries of about 1000 manuscripts, and then found a few others by chance. But they are very precious because they record the results of actual

25 For Cardinal Pierre d'Ailly (ca 1350-ca 1420) and Jean Gerson (1363-1429) on astrology see Lynn Thomdike, $A$ Hisfory of Magic and Experimental Science, New York, 1934, vol. 4, pp. 101-31. 
calculations. My information relates only to England. It would be very interesting to compare the computations of fifteenth-century Genoese or Spanish astrologers, but this has not been possible. Please indulge me by allowing me to continue this argument by way of analogy.

Calculating a horoscope is quite a computational feat. Astrologers performed the same tasks as navigators like Columbus, calculating planetary longitudes with the aid of an astrolabe and tables, or predicting the times of eclipses at different longitudes. It should not be very surprising to find how unusual it was, before the late fifteenth century, to calculate accurate boroscopes. The horoscopes attributed to Adelard of Bath in the twelfth century, for example, are full of errors and strange calculations. The harder planetary calculations be simply omitted.

The astrologers whose work I know never took observations, and only the most scrupulous bothered to use tables which gave celestial longitudes correct for the place to which the horoscope related. Often they would use one set of tables for one part of the calculations and another, calculated for a different longitude, for the rest. Scholars who have become familiar with this state of affairs have generally explained it as either incompetence or (more sinisterly) as evidence of the weak-mindedness of those duped by astrology. Their calculations, like their predictions, were open to manipulation. It recalls Columbus, the 'liar and the cheat', the incompetent, the explorer who could not even leave a clear black line on a map to posterity.

Yet astrologers, like Columbus, were not really in the business of discovering new worlds. The fragile futures they predicted could only be conceived within the cosmology which the astrologers had established by diligent reading and acceptance of authority. In medieval English libraries, the authorities were clear: Ptolemy and Firmicus Maternus among the ancients, Albumasar, Alcabicius, Alkindi, Messahalla, Haly Abenragel, and a few English authorities, especially Roger Bacon and Robert Grosseteste, among the moderns. ${ }^{26}$

How can a prediction of the future be accurate, as the astrologer labours to choose an authoritative interpretation consistent with the cosmology generated by Albumasar and Alkindi, Firmicus Maternus, and Roger Bacon?

26 For details see Hilary Carcy, Courting Disaster: Astrology at the English Court and University in the Later Middle Ages, London, 1992, Appendix I. 
And when the future events have been reached, how can they do other than fulfil the astrologer's predictions? This seems to be the best way to explain the existence of texts such as Symon de Phares Account of Famous Astrologers, written in Paris in the fifteenth century and dedicated to Charles VIII of France. ${ }^{27}$ For Symon, the Hundred Years War was a testimony to the expertise and taste of the French and English nobility and the astrologers they patronized. The Hundred Years War is imposed on this imaginary cosmology as Columbus imposed his voyage on an imagined world.

Let me end with a final example of the power of the imagined cosmology in astrology, a power all the stronger for being combined with a technology of calculation and instrumentation. Some time before the marriage of Henry $\mathrm{V}$ of England, an anonymous astrologer calculated a nativity, that is, a birth horoscope, and wrote a small treatise to consider a number of matters relating to the king, including his personality, bealth, prospects for marriage, and time of death. ${ }^{28}$ It is this last factor which shows that this horoscope must have been written before 1422, when Henry $V$ died at Bois de Vincennes, of dysentery. For this horoscope has a surprising correction on the scheme of the horoscope. In the first paragraph of the treatise the date of birth has been changed from 1369 to 1376, and 1376 is the date that appears in the centre of the scheme.

Both dates are wrong. The date most frequently cited for the birth of Henry V is 16 September 1387. Why the change? The change was made in order that there should be a correspondence between the initial calculations and the prediction in chapter five that Henry would live for fifty-two years. So why not change this figure instead? It seems altogether mysterious. But I think one explanation has to be that the imagined cosmology of the astrologer and the lines of contingency which the treatise has prepared for Henry $\mathrm{V}$ are more powerful than 'reality'. If it was predicted that he should live for fifty-two years, then he must have been born in 1376. This makes nonsense of the initial calculations of course, but, as for Columbus, the calculations were something of a struggle for the form of the thing in any case.

27 lbid., ch. 6; also Ernest Wickersheimer, ed., Receuil des plus celebres astrologues et quelques hommes doctes faict par Symon de Phares, Paris, 1929. ${ }^{28}$ See Carey, Courting Disaster, pp. 129-36, for discussion of this tract. 
It would not do for a paper about 'New worlds, imaginary spaces and contingent reality' to lay down too many black lines in the way of conclusions. No doubt Jonatbon King will continue to try and verify the real path of the first voyage of Columbus. But I would prefer to leave him in his imaginary space, just as Henry $V$ was suspended in his imaginary future, a future in which he was born eleven years before his time. In this space Columbus can continue to voyage to the East of his imagination, unlucky to miss Cipango and ever watchful to meet the emissaries of the Great Khan.

Hilary M. Carey Department of History University of Newcastle 